\title{
BIBLIOMETRIC ANALYSIS OF DEMATEL METHOD
}

\author{
Gözde Koca ${ }^{1 *}$ and Seda Yıldırım ${ }^{1}$
}

1 Bilecik Seyh Edebali University, Department of Business Administration, Bilecik, Turkey

Received: 11 January 2021;

Accepted: 3 February 2021;

Available online: 11 February 2021.

Original scientific paper

Abstract: In this study, a bibliometric analysis of the studies evaluated with DEMATEL (Decision Making Experiment and Evaluation Laboratory Method), one of the MCDM methods in Web of Science, was performed according to various performance indicators. The total number of DEMATEL publications examined is 1963 documents. When DEMATEL studies are evaluated in terms of countries, it is seen that China is the leader (553 documents; 28.17\%). The most cooperative country is China. The country with the highest h-index is Taiwan (62). Journal of Cleaner Production is the most efficient journal (96; 4.88\%). National Chiao Tung University (102, 5.19\%) is ranked as the most efficient institution in DEMATEL research. Among the most used words are "Model", "DEMATEL", "Selection", "Management", "fuzzy DEMATEL".

Key words: Multi-Criteria Decision Making, Bibliometric, Web of Science, DEMATEL.

\section{Introduction}

Decision making can be defined as individuals and organizations choosing the best alternative under current conditions to achieve their goals. Decision making is an interdisciplinary field of research that attracts researchers and academics in almost every field. While intelligence, intuition and experience are important in decision making, it is equally important to use scientific methods.

MCDM methods (Multi-criteria decision-making methods) have been developed for the correct evaluation of multiple different criteria in solving complex problems. MCDM methods refer to the process of evaluating many criteria in a problem at the same time and assigning numerical evaluation to alternatives. MCDM allows decisionmakers to make evaluations and make decisions in multiple dimensions by bringing together multiple disciplines such as mathematics, management, social sciences, and economics (Yıldırım \& Önder, 2018: 15). Each method has solution logic in itself (Çelikbilek, 2018: 3). The MCDM process consists of two stages. In the first of these stages, all the objectives and provisions given according to the alternatives are

* Corresponding author.

E-mail addresses: gozde.koca@bilecik.edu.tr (G. Koca), sdayldrmm@gmail.com (S. Yıldırım) 
Koca and Yıldırım/Decis. Mak. Appl. Manag. Eng. 4 (1) (2021) 85-103

brought together, in the second stage; the most appropriate decision is made by evaluating the alternatives among the combined provisions. (Aytaç \& Gürsakal, 2015: 250).

DEMATEL (The Decision Making Trial and Evaluation Laboratory), one of the MCDM methods, was developed in 1972 by the Battelle Memorial Institute of Geneva Research Center. The method is used in solving complex problem groups (Shgeh et al., 2010: 277-282). The advantage of the DEMATEL method is that it separates the distributor and receiver groups in the problem and determines the relationships between the criteria based on Graph Theory (Impact-Directional Diagram) (Lin \& Tzeng, 2009: 9686). The DEMATEL method, which assumes that all criteria determined for the decision-making problem are in interaction with each other, evaluates the effect levels among the criteria. In the method, factors that are higher than the other criteria are called distributive, and criteria whose exposure level is higher than the effect on the system are called buyers (Karaoğlan, 2016: 13).

The increasing interest in MCDM methods has caused the publication of DEMATEL method to increase continuously. In this study, bibliometric analysis was performed on the studies related to the method to interpret and summarize the information confusion caused by the continuous increase of the publications made with the DEMATEL method. The reason why the DEMATEL method is examined in this study is that it covers a very different literature that contributes from different disciplines. Apart from this, it is to show how the method is examined in different disciplines by revealing causality and by revealing the importance of its differentiation from other MCDM methods. Bibliometric analysis is an analysis method that examines scientific studies with the help of numerical analysis and statistics and shows the activities and current status of scientific studies in the field (Çetinkaya Bozkurt \& Çetin, 2016: 32). Accordingly, bibliometric analysis reveals the productivity of countries, institutions and authors, citation analysis of countries, institutions and authors, which type of documents are used more, and how much the documents are distributed, and cooperation maps.

For the research, the 1963 document searched from the Web of Science database with the subject "DEMATEL" on 12.12.2020 was found in the bibliometrix library of the R Studio program and analyzed with biblioshiny. All studies on the DEMATEL method between 1999 and 2020 in the Web of Science database were included in the analysis. Along with the analysis, annual studies and total citation rates, the productivity of countries, the number of citations and the cooperation map between countries, the most used journals and the number of citations in the studies conducted on the subject, the most efficient universities, the fields of science in which the DEMATEL method is used and In which journals the studies were published the most, the most productive authors and citation rates, the most cited articles and the most used words in the articles written on the subject and the conceptual structure of the field were shown.

\section{Literature Overview}

The study conducted by Cole and Eales in 1917 in the literature is known as the first bibliometric study. In this study; Analyzes of studies published in the field of anatomy between 1550-1860 were made. After this study, an analysis was made in the field of historical science by E.Wyndham Hulme, a librarian at the British Patent Office in 1923. Later, in 1927, P.L.K. Gross and E.M. A citation analysis study was conducted by Gross to evaluate the bibliography of the articles published in the Journal of the 
Biblometric analysis of DEMATEL method

American Chemical Society. The first two studies were based on bibliographic features, not citations, and in Gross \& Gross's study, citation analysis was performed (Lawani, 1981: 295, Hotamışlı \& Erem, 2014: 3). On the subject of MCDM, there are many studies conducted in the related literature. Popular tools such as VOSviewer, RBibliometric Package were used in some of these studies. Bibliometric studies made using popular tools in the field of MCDM are summarized in Table 1 below.

Table 1. Bibliometric Studies Using Popular Tools in the MCDM Field

\begin{tabular}{|c|c|c|c|c|}
\hline Authors & Year & Keyword Used & $\begin{array}{l}\text { Time } \\
\text { Span }\end{array}$ & $\begin{array}{c}\text { Number of } \\
\text { Publications } \\
\text { Reviewed }\end{array}$ \\
\hline Bragge et al. & 2010 & $\begin{array}{l}\text { Multi objective, Multi } \\
\text { criteria }\end{array}$ & $\begin{array}{l}1970- \\
2007\end{array}$ & 15198 \\
\hline $\begin{array}{l}\text { Guerrero-Baena } \\
\text { et al. }\end{array}$ & 2014 & MCDM & $\begin{array}{l}1980- \\
2012\end{array}$ & 347 \\
\hline Zavadkas et al. & 2014 & MCDM review papers & $\begin{array}{l}1990- \\
2013\end{array}$ & 71 \\
\hline Tramarico et al. & 2015 & $\begin{array}{c}\text { Analytic Hierarchy Process } \\
\text { and Supply Chain }\end{array}$ & $\begin{array}{l}1990- \\
2014\end{array}$ & 116 \\
\hline Blanco-Mesa et al. & 2017 & Fuzzy decision-making & $\begin{array}{l}1970- \\
2014\end{array}$ & 8135 \\
\hline Liu \& Liao & 2017 & Fuzzy Decision & $\begin{array}{l}1970- \\
2015\end{array}$ & 13901 \\
\hline $\begin{array}{c}\text { Zyoud and } \\
\text { Funchs-Hanusch }\end{array}$ & 2017 & AHP ve TOPSIS & $\begin{array}{l}1976- \\
2016\end{array}$ & $\begin{array}{l}10188 \text { AHP } \\
2412 \text { TOPSIS }\end{array}$ \\
\hline Peng \& Dai & 2018 & Neutrosophic set & $\begin{array}{l}1998- \\
2017\end{array}$ & 137 \\
\hline Yu et al. & 2018 & $\begin{array}{l}\text { Multiple criteria decision- } \\
\text { making }\end{array}$ & $\begin{array}{l}1977- \\
2016\end{array}$ & 4464 \\
\hline Liao et al. & 2019 & Hesitant fuzzy sets & $\begin{array}{l}2009- \\
2018\end{array}$ & 484 \\
\hline Morkūnaitè et al. & 2019 & $\begin{array}{l}\text { Cultural heritage buildings } \\
\text { with MCDM }\end{array}$ & $\begin{array}{c}1994- \\
2018\end{array}$ & 1039 \\
\hline
\end{tabular}

There are literature reviews in the field of MCDM without using popular bibliometric tools. Abu-Taha (2011) reviewed more than 90 publications on MCDM in the field of renewable energy. He summarized both the application areas and the methodologies used in these publications. As a result of the literature review, it is revealed that AHP is the most used method among all MCDM methodologies. Kahraman et al. (2015) examined the MCDD literature by dividing it into two parts as multi-specific and multi-purpose. In particular, they focused on multi-purpose decision making. They provided tables and graphs for each method (Fuzzy AHP, Fuzzy VIKOR, Fuzzy TOPSIS, Fuzzy ELECTRE, etc.). Mardani, et al. (2015) examined a total of 393 articles published in more than 120 peer-reviewed journals between 2000 and 2014. Especially in the fields of energy, environment, and sustainability, they found that MCDM methods are frequently used. Gül et al. (2016) conducted a literature review on VIKOR and Fuzzy VIKOR applications and reviewed 343 publications in total. This comprehensive literature review they have done provides insight into VIKOR applications for researchers and practitioners. In their study, Renganath \& Suresh (2016) analyzed the literature of MCDM methods used in supplier selection. After all, they said that the most popular method was fuzzy TOPSIS. Stojčić et al. (2019) 
Koca and Yıldırım/Decis. Mak. Appl. Manag. Eng. 4 (1) (2021) 85-103

reviewed the literature on the application of MCDM methods in the field of sustainable engineering. They analyzed 108 articles scanned in the Web of Science (WoS) database between 2008-2018. As a result, they found that sustainable engineering is a very suitable field for the use of MCDM. Liu et al. (2019) conducted a comprehensive review of FMEA (Error Type and Effects Analysis) studies using MCDM approaches to evaluate and prioritize error types. They reviewed 169 articles published between 1998-2018. This research sup0ports and provides insight into academics and practitioners in effectively adopting MCDM methods to overcome the shortcomings of traditional FMEA. Chowdhury and Paul (2020) conducted a literature analysis of MCDM methods used in corporate sustainability between 2007 and 2019. As a result of this analysis, in which they examined 52 publications, they determined that the most used methods were AHP and TOPSIS.

\section{Method}

Bibliometric analysis is to make the scope of research in a particular area of interest both quantitatively and qualitatively (Ellegaard and Wallin, 2015: 1809). Bibliometry developed for library and information sciences is used to classify research according to publications, times, and journals (Merigo \& Yang, 2017: 37). In other words, bibliometry strengthens the scientific literature by understanding the research literature better (Osareh, 1996: 149). Stevens (1953) divided bibliometric studies into two main areas as seen below. Descriptive studies contribute to authors, journals, years, and discipline by categorizing publications by country, while evaluators show where and how many publications are cited.

1. Descriptive studies

- Country or geographic location

- Timespan

Discipline or subject area

2. Evaluative studies

- Source

- Citation

The analysis made allows identifying early trends in studies conducted in any field (Ellegaard and Wallin, 2015: 1809). In general terms, it describes scientific collaboration through collaborations between researchers, institutions, and countries. Some new tools have been introduced to generate more broadcast data and provide a wide variety of indicators as listed in Table 2. In this study, R-Biblioshiny was used.

Table 2. Popular Tools for Bibliometric Analysis

\begin{tabular}{cc}
\hline Tools & Practitioners \\
\hline BibExcel & Olle Persson \\
Authors & Authors ' frequency tables \\
Pajek & Vladimir Batagelj and Andrej Mrvar \\
CiteSpace & ChaomeiChen \\
VOSviewer & Nees Jan Van Eck and LudoWaltman \\
R-Bibliometric Package & Massimo Aria and Carrado Cuccurullo \\
\hline
\end{tabular}




\section{Results}

1963 DEMATEL publications in 800 sources (Journals, Books, etc) between 1999 and 2020 in the WOS database were examined. DEMATEL publications mostly consist of articles, book chapters, early access, proceedings papers and, review publications. Average citations per document are 15,39 and Average citations per year per doc is 3.274 .

Figure 1 shows the annual number of citations of the studies conducted with the DEMATEL method. The most citations to DEMATEL's work took place in 2015 and 2018. It is seen that DEMATEL studies get quite high citations. This shows that the method has a very dynamic structure. The distribution of the examined publications by years is given in Figure 2. As can be understood from Figure 2, the studies made with the DEMATEL method have increased over the years. Especially after 2015, the number of studies conducted with the method has increased. It is seen that most work on the method is in 2020.

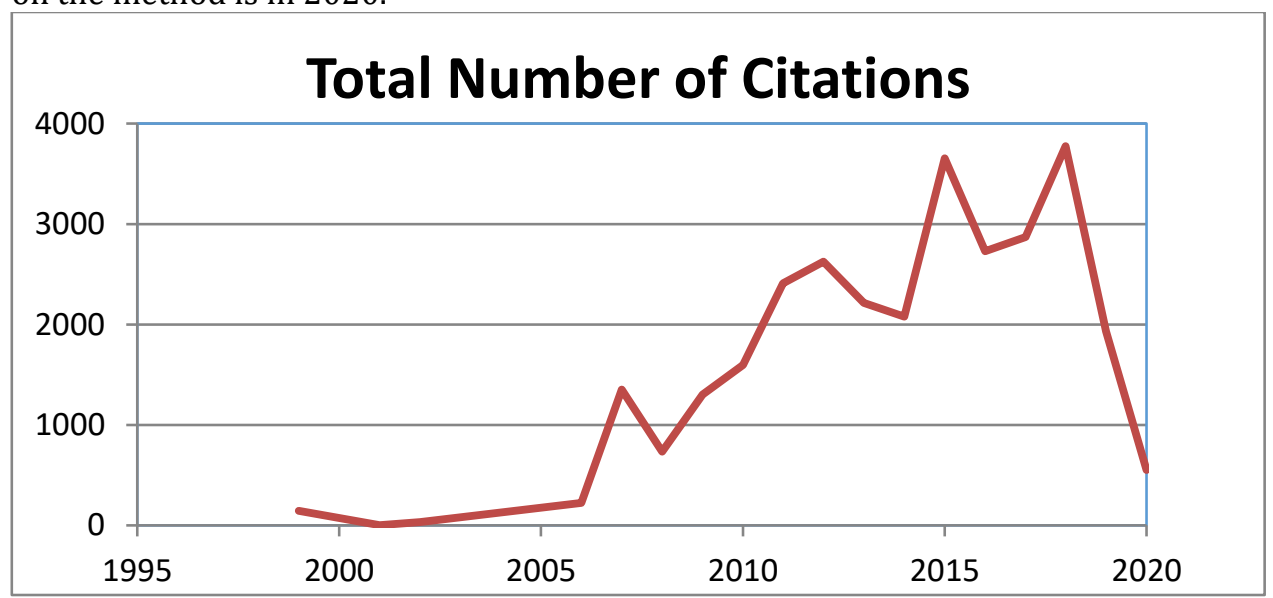

Figure 1. Number of citations by years

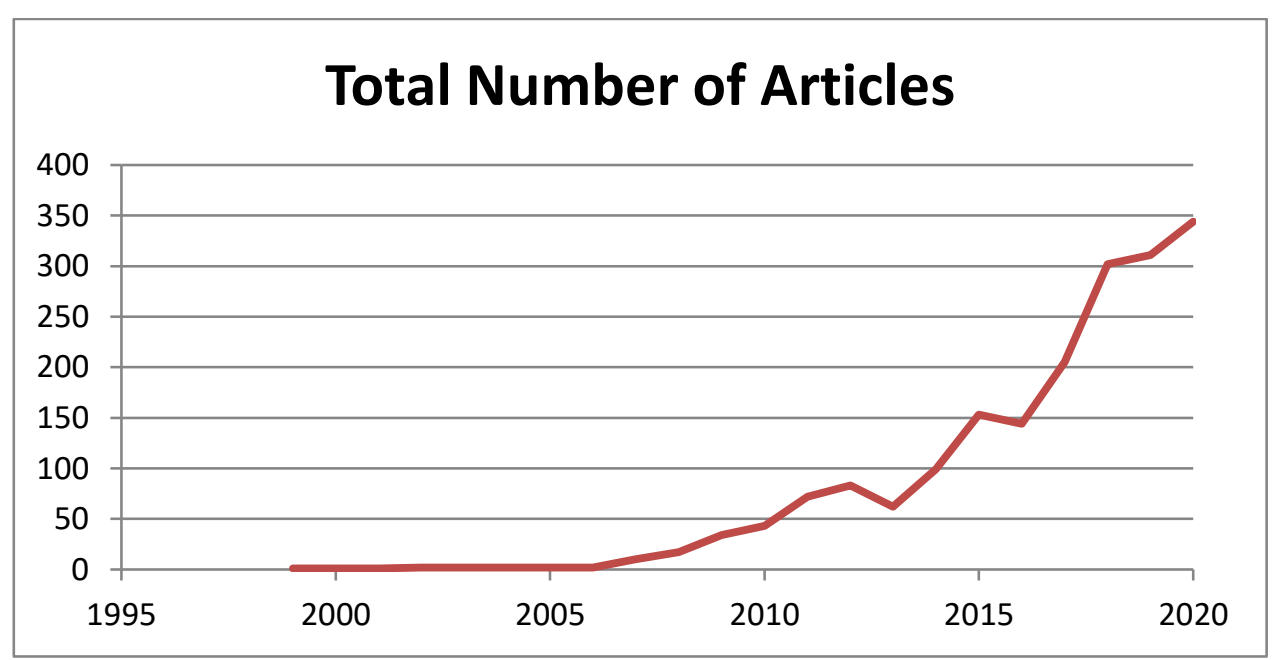

Figure 2. Number of articles by years 
Koca and Yıldırım/Decis. Mak. Appl. Manag. Eng. 4 (1) (2021) 85-103

Table 3 shows the 20 most productive countries in the DEMATEL method. According to the table, it is seen that the most productive country is China (553; 28.171\%). After China, respectively, Taiwan (519; 26.439\%), Iran (251; 12.787\%), India $(241 ; 12.277 \%)$ and Turkey $(184 ; 9.373 \%)$ are ranked. With the highest $\mathrm{h}$-index of 62, and it was recorded by Taiwan China (41), India (29), Iran (27), Turkey (24), and the United States (24) respectively. Considering the citation rates of the countries, it is seen that the most cited country is Taiwan (12884). After Taiwan, respectively, China (6228), India (2892), Iran (2878), and Turkey (2499) are ranked. According to the number of studies of the countries, it is seen that the country with the highest citation average is Denmark with $50.87 \%$.

Table 3. Ranking of top twenty most productive countries

\begin{tabular}{cccccc}
\hline Country & $\begin{array}{c}\text { No. of } \\
\text { documents }\end{array}$ & $\%$ & h-index & $\begin{array}{c}\text { No. Of } \\
\text { citations }\end{array}$ & Average citations \\
\hline CHINA & 553 & 28,171 & 41 & 6228 & 11,26 \\
TAIWAN & 519 & 26,439 & 62 & 12884 & 24,82 \\
IRAN & 251 & 12,787 & 27 & 2878 & 11,42 \\
INDIA & 241 & 12,277 & 29 & 2892 & 12,00 \\
TURKEY & 184 & 9,373 & 24 & 2499 & 13,58 \\
USA & 74 & 3,770 & 24 & 1710 & 23,11 \\
ENGLAND & 63 & 3,209 & 17 & 839 & 13,32 \\
MALAYSIA & 57 & 2,904 & 16 & 679 & 11,91 \\
AUSTRALIA & 41 & 2,089 & 11 & 492 & 12,00 \\
SPAIN & 34 & 1,732 & 11 & 460 & 13,53 \\
SERBIA & 32 & 1,630 & 16 & 1039 & 32,47 \\
DENMARK & 31 & 1,579 & 23 & 1577 & 50,87 \\
POLAND & 31 & 1,579 & 7 & 217 & 7,00 \\
LITHUANIA & 30 & 1,528 & 13 & 796 & 26,53 \\
CANADA & 29 & 1,477 & 8 & 354 & 12,21 \\
ITALY & 27 & 1,375 & 11 & 467 & 17,30 \\
PHILIPPINES & 24 & 1,223 & 9 & 476 & 19,83 \\
SOUTH KOREA & 24 & 1,223 & 7 & 284 & 11,83 \\
JAPAN & 23 & 1,172 & 8 & 524 & 22,78 \\
INDONESIA & 21 & 1,070 & 3 & 128 & 6,10 \\
\hline
\end{tabular}

The world density map is shown in Figure 3 below. The countries where DEMATEL studies are carried out the most are listed from dark to light. Countries with gray color do not have studies on the method. 


\section{Country Scientific Production}

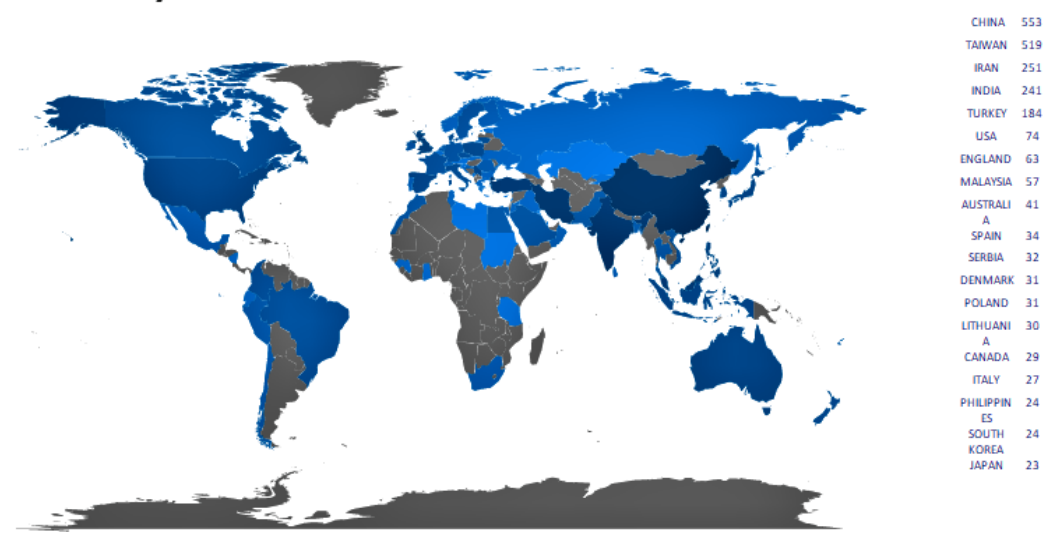

Figure 3. The world density map

The most cooperating twenty countries according to the number of documents are shown in Table 4. According to the table, among the countries with the highest cooperation, Taiwan-China is the first with 74 documents, the USA-China is the second with 31 documents, and the UK-China is the third with 22 documents.

Table 4. The twenty most cooperative countries according to the number of documents

\begin{tabular}{ccc}
\hline From & To & Frequency \\
\hline Taiwan & China & 74 \\
USA & China & 31 \\
United Kingdom & China & 22 \\
India & United Kingdom & 20 \\
Turkey & China & 20 \\
China & Australia & 17 \\
Iran & Lithuania & 16 \\
Iran & Malaysia & 14 \\
India & Denmark & 11 \\
Iran & USA & 11 \\
Malaysia & Saudi Arabia & 11 \\
China & Denmark & 10 \\
China & Canada & 9 \\
India & China & 9 \\
India & USA & 9 \\
Iran & Australia & 9 \\
Taiwan & USA & 9 \\
India & Lithuania & 8 \\
India & Spain & 8 \\
Taiwan & Philippines & 8 \\
& &
\end{tabular}

World cooperation map is given in Figure 4. The countries where the lines are concentrated are determined as the countries that cooperate most with other 
Koca and Yıldırım/Decis. Mak. Appl. Manag. Eng. 4 (1) (2021) 85-103

countries. Accordingly, China the country with the highest cooperation with other countries, India, Iran, Taiwan, Turkey, the UK and the US appear to be.

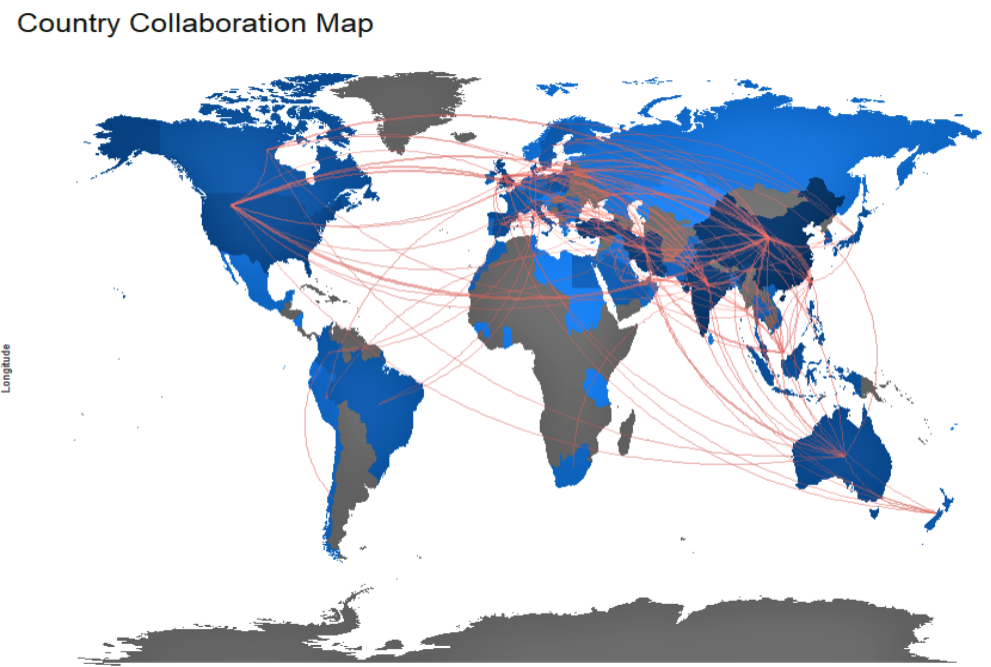

Figure 4. World cooperation map

Table 5 shows the sources of DEMATEL publications. As shown in Table 5 in this study, Journal of Cleaner Production (96; 4,888\%) has been the most comprehensive source of DEMATEL research. Then, Sustainability $(90 ; 4,582 \%)$ and Expert System Applications $(77 ; 3,921 \%)$ journals follow. The most cited journal was determined to be the Expert System Applications journal with 7074 citations. Besides, Expert System Applications journal has the highest h-index (48) and the highest average citation rate (91.87). Then, it was seen that Journal of Cleaner Production ranked second with 2895 citations. The journals with the highest h-indexes after the Expert System Application journal are Journal of Cleaner Production (28), Sustainability (16), Computers \& Industrial Engineering (16), Applied Soft Computing (16), respectively.

Table 5. Sources of DEMATEL publications

\begin{tabular}{|c|c|c|c|c|c|}
\hline Sources & Articles & $\%$ & $\begin{array}{c}\mathrm{h}- \\
\text { index }\end{array}$ & $\begin{array}{c}\text { Total } \\
\text { citations }\end{array}$ & $\begin{array}{l}\text { Average } \\
\text { citations }\end{array}$ \\
\hline Journal of Cleaner Production & 96 & 4,888 & 28 & 2895 & 30,16 \\
\hline Sustainability & 90 & 4,582 & 16 & 741 & 8,23 \\
\hline $\begin{array}{l}\text { Expert Systems with } \\
\text { Applications }\end{array}$ & 77 & 3,921 & 48 & 7074 & 91,87 \\
\hline $\begin{array}{l}\text { Computers \& Industrial } \\
\text { Engineering }\end{array}$ & 32 & 1,629 & 16 & 844 & 26,38 \\
\hline Applied Soft Computing & 26 & 1,324 & 16 & 917 & 35,27 \\
\hline $\begin{array}{l}\text { Benchmarking-An International } \\
\text { Journal }\end{array}$ & 21 & 1,120 & 8 & 167 & 7,59 \\
\hline $\begin{array}{l}\text { International Journal of Fuzzy } \\
\text { Systems }\end{array}$ & 20 & 1,018 & 10 & 387 & 19,35 \\
\hline $\begin{array}{c}\text { Mathematical Problems in } \\
\text { Engineering }\end{array}$ & 20 & 1,018 & 7 & 216 & 10,80 \\
\hline
\end{tabular}


Biblometric analysis of DEMATEL method

International Journal of

$\begin{array}{cccccc}\begin{array}{c}\text { Environmental Research and } \\ \quad \text { Public Health }\end{array} & 19 & 0,967 & 5 & 91 & 4,79 \\ \begin{array}{c}\text { Symmetry-Basel } \\ \text { Resources Conservation and }\end{array} & 19 & 0,967 & 5 & 154 & 8,11 \\ \quad 18 & 0,916 & 12 & 573 & 31,83 \\ \quad \begin{array}{c}\text { Recycling } \\ \text { Ieee Access }\end{array} & 17 & 0,866 & 4 & 40 & 2,35 \\ \begin{array}{c}\text { International Journal of } \\ \text { Production Research }\end{array} & 17 & 0,866 & 11 & 483 & 28,41 \\ \begin{array}{c}\text { Journal of Intelligent \& Fuzzy } \\ \quad \text { Systems }\end{array} & 17 & 0,866 & 4 & 71 & 4,18 \\ \begin{array}{c}\text { International Journal of } \\ \text { Information Technology \& }\end{array} & 16 & 0,815 & 8 & 192 & 12,00 \\ \quad \begin{array}{c}\text { Decision Making } \\ \text { Soft Computing }\end{array} & 16 & 0,815 & 6 & 288 & 18,00 \\ \quad \begin{array}{c}\text { International Journal of } \\ \text { Production Economics }\end{array} & 15 & 0,764 & 13 & 1004 & 66,93 \\ \quad \text { Safety Science } & 15 & 0,764 & 9 & 500 & 33,33 \\ \quad \text { Energies } & 14 & 0,713 & 5 & 68 & 4,86 \\ \begin{array}{c}\text { Technological And Economic } \\ \text { Development of Economy }\end{array} & 14 & 0,713 & 8 & 331 & 23,64\end{array}$

Table 6 shows the 20 most active universities in DEMATEL research. Accordingly, it is seen that the most productive university in DEMATEL studies is National Chiao Tung University in Taiwan with 102 documents $(5,196)$. Islamic Azad University in Iran ranks second with 90 documents $(4,585)$ and Nan Kai University Technology in China is third with 86 documents $(4,381)$. The most cited university is National Chiao Tung University with 4344 citations and an average citation rate of $42.59 \%$. Also, National Chiao Tung University has the highest h-index (37).

Table 7 shows the ranking of the twenty most common areas in DEMATEL studies. Most of the published studies are in the field of Computer Science Artificial Intelligence $(332 ; 16,904)$ and it was seen that the most used journal in this field was Expert System With Applications (77; 23,193\%). Following this area, the most common areas are Environmental Sciences (288; 14.664\%), Operations Research Management Science (285; 14.511\%), Management (272; 13.849\%), Green Sustainable Science Technology $(235 ; 11.965 \%)$.

Table 8 shows the most productive twenty authors on DEMATEL research. According to the table, with 121 documents (6.161\%), Tzeng G.H. seems to be. Also, Tzeng G.H is the author with the highest h-index (34) and the highest number of citations (4117). Tzeng G.H. It is seen that the most prolific authors are Tseng M.L. (38), Dincer H. (36), and Liou J.J.H (36). Also, Tseng M.L. is the second most cited author (1605). 
Koca and Y1ldırım/Decis. Mak. Appl. Manag. Eng. 4 (1) (2021) 85-103

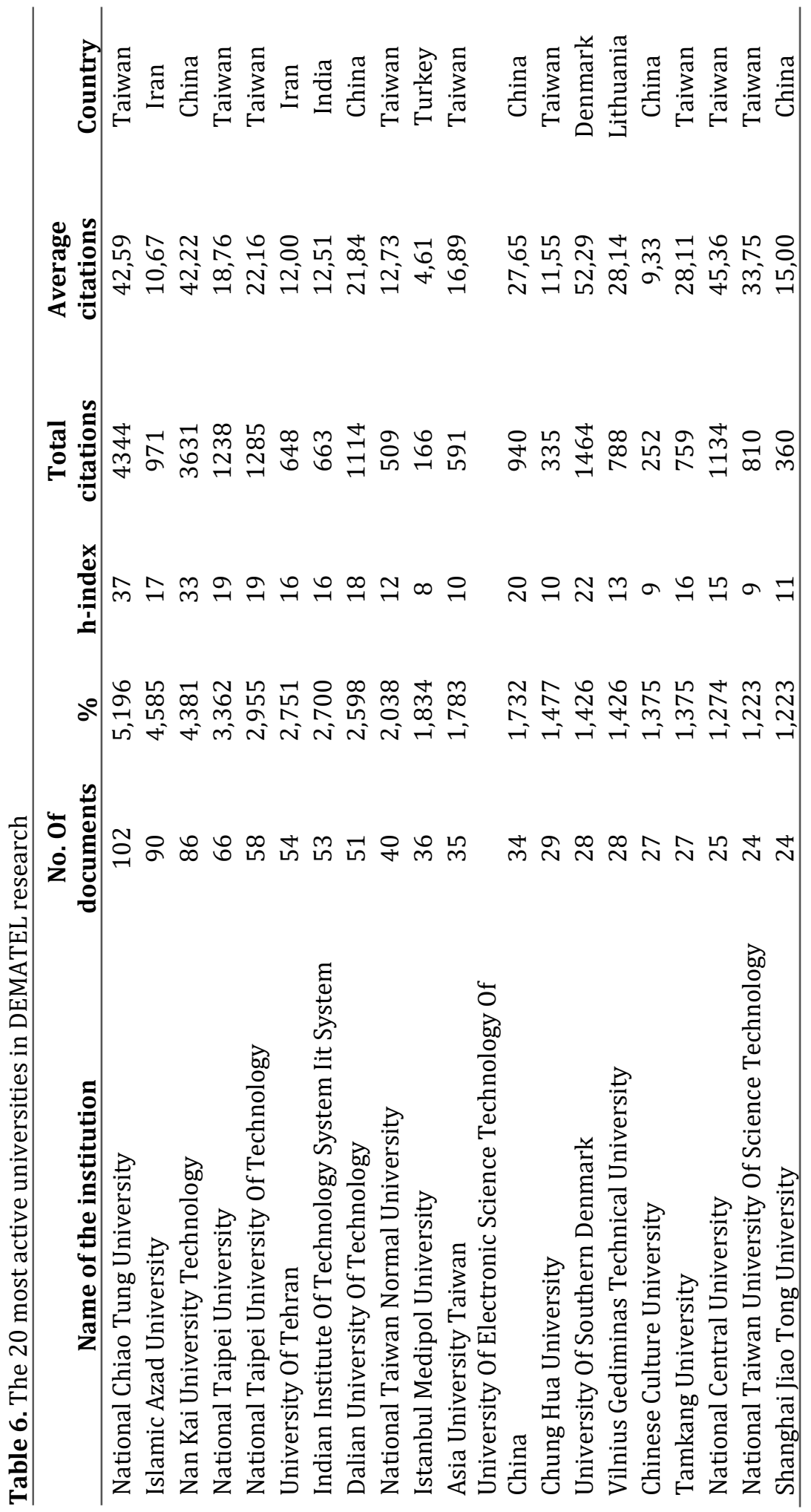


Biblometric analysis of DEMATEL method

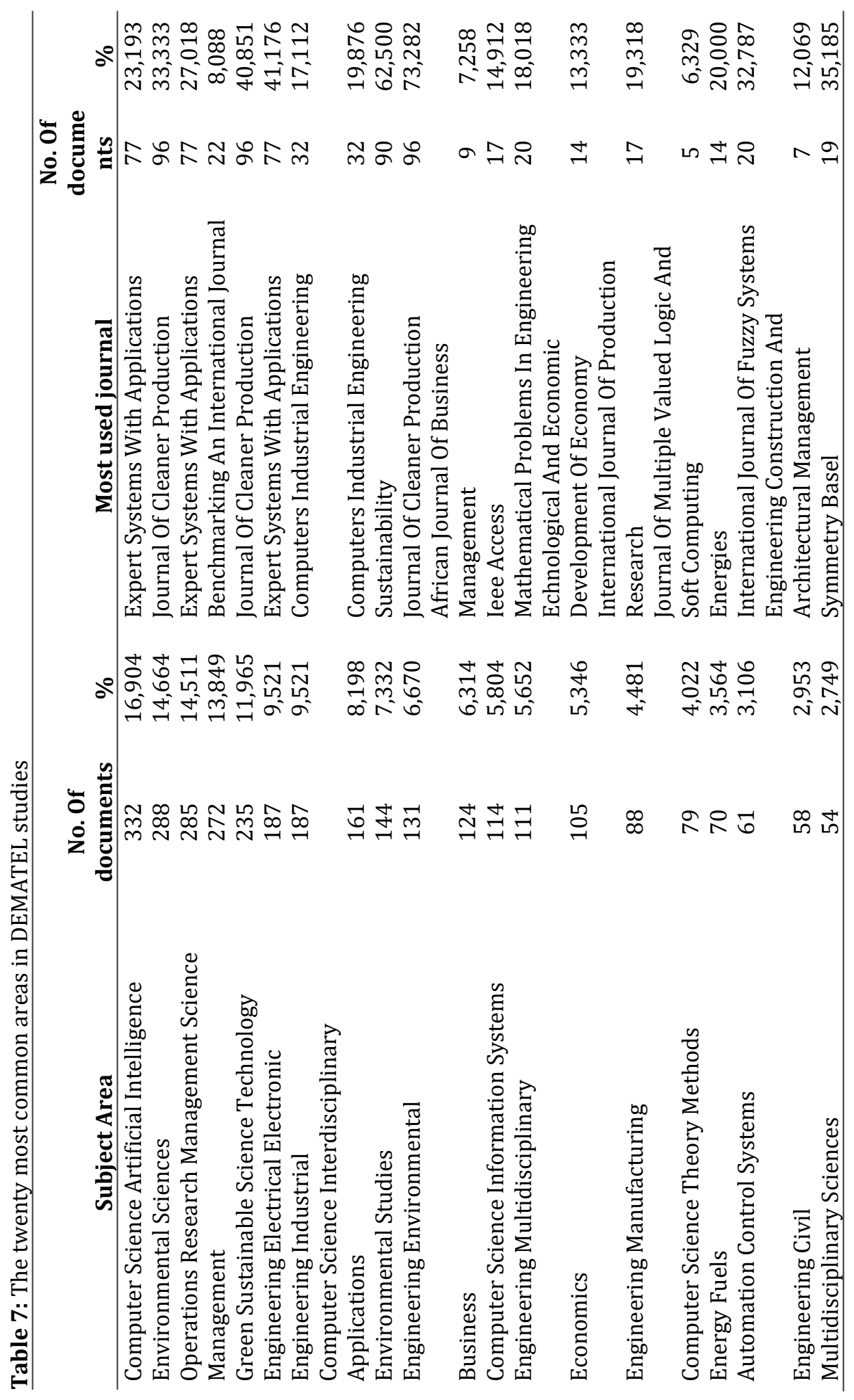


Koca and Yıldırım/Decis. Mak. Appl. Manag. Eng. 4 (1) (2021) 85-103

Table 8. The most productive twenty authors on DEMATEL research

\begin{tabular}{cccccc}
\hline Authors & Articles & $\%$ & h-index & $\begin{array}{c}\text { Total } \\
\text { citations }\end{array}$ & $\begin{array}{c}\text { Average } \\
\text { citations }\end{array}$ \\
\hline Tzeng GH & 121 & 6,161 & 34 & 4117 & 34,02 \\
Tseng ML & 38 & 1,935 & 19 & 1605 & 42,24 \\
Dincer H & 36 & 1,833 & 8 & 165 & 4,58 \\
Liou JJH & 36 & 1,833 & 17 & 1115 & 30,97 \\
Huang CY & 35 & 1,782 & 7 & 394 & 11,26 \\
Yuksel S & 32 & 1,629 & 8 & 161 & 5,03 \\
Kumar A & 26 & 1,324 & 9 & 230 & 8,85 \\
Pamucar D & 23 & 1,171 & 13 & 826 & 35,91 \\
Govindan K & 22 & 1,120 & 16 & 1202 & 54,64 \\
Liu HC & 21 & 1,069 & 16 & 1054 & 50,19 \\
Mangla SK & 21 & 1,069 & 11 & 440 & 20,95 \\
Tsai SB & 21 & 1,069 & 14 & 464 & 22,10 \\
Chuang YC & 20 & 1,018 & 8 & 315 & 15,75 \\
Luthra S & 20 & 1,018 & 12 & 478 & 23,90 \\
Lee YC & 17 & 0,866 & 8 & 279 & 16,41 \\
Zavadskas EK & 17 & 0,866 & 13 & 741 & 43,59 \\
Sarkis J & 16 & 0,815 & 12 & 686 & 42,88 \\
Wu KJ & 16 & 0,815 & 9 & 429 & 26,81 \\
Wu HH & 15 & 0,764 & 8 & 484 & 32,27 \\
Hsu Cc & 14 & 0,713 & 11 & 390 & 27,86 \\
\hline Table 9, the mos
\end{tabular}

In Table 9, the most cited ten articles about the DEMATEL method are given. The most cited article in DEMATEL with 570 citations is Tzeng G.H., et al "Evaluating intertwined effects in e-learning programs: A novel hybrid MCDM model based on factor analysis and DEMATEL" (2007). In this article, the factors of the e-learning program are analyzed. The second most cited article with 500 citations, Wu, W.W. \& Lee, Y.T. "Developing global managers' competencies using the fuzzy DEMATEL method" (2007). The article by Buyukozkan \& Cifci (2012) titled "A novel hybrid MCDM approach based on fuzzy DEMATEL, fuzzy ANP, and fuzzy TOPSIS to evaluate green suppliers" is ranked third with 444 citations 
Biblometric analysis of DEMATEL method

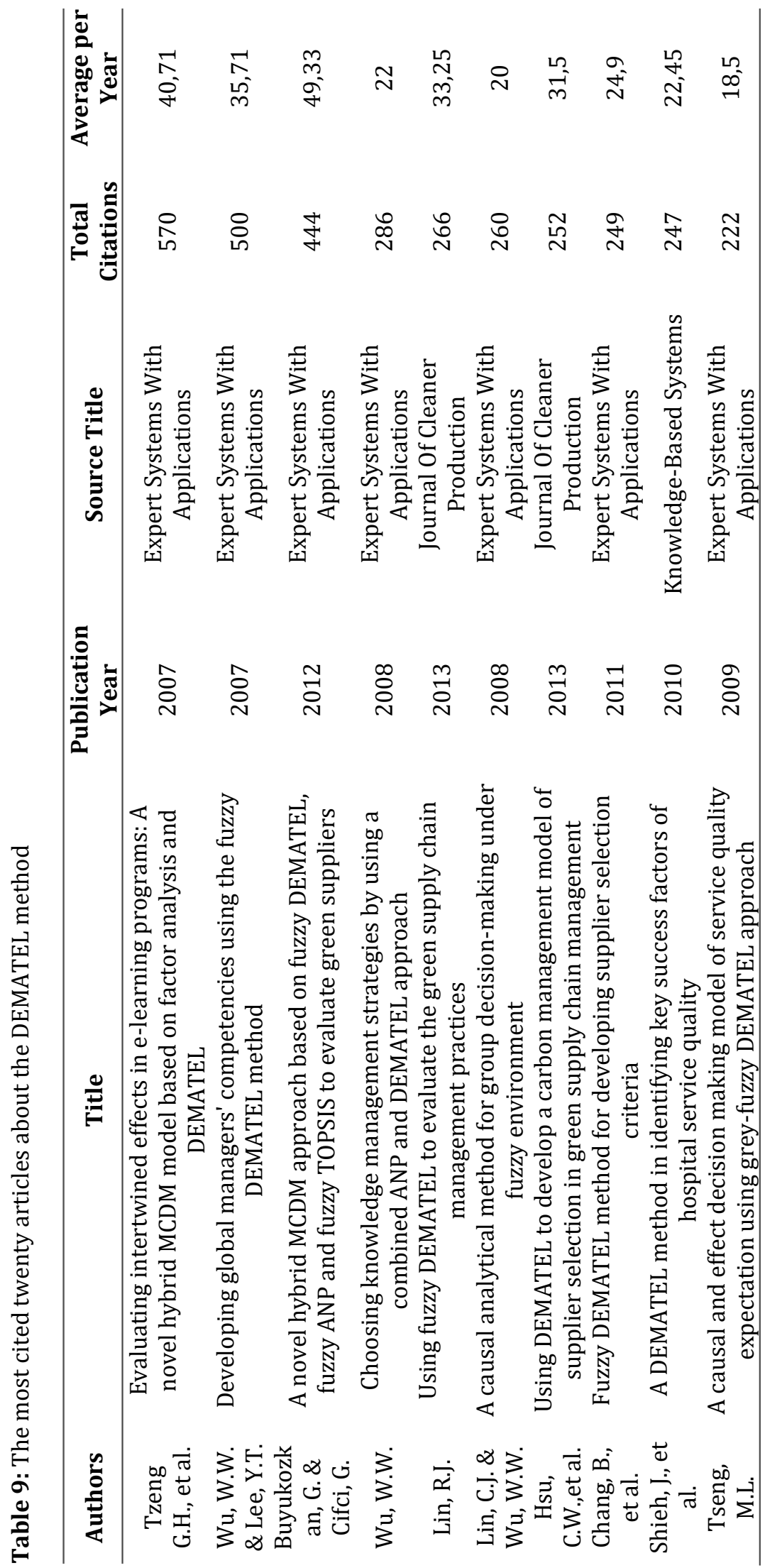


Koca and Y1ldırım/Decis. Mak. Appl. Manag. Eng. 4 (1) (2021) 85-103

The most commonly used keywords in DEMATEL method are shown in Figure 5. Keyword analysis shows common keywords used by authors. Accordingly, the most used keyword in DEMATEL is seen as "model". In addition, the words "dematel", "selection", "management", "performance", "anp", "decision making" are the most common keywords.

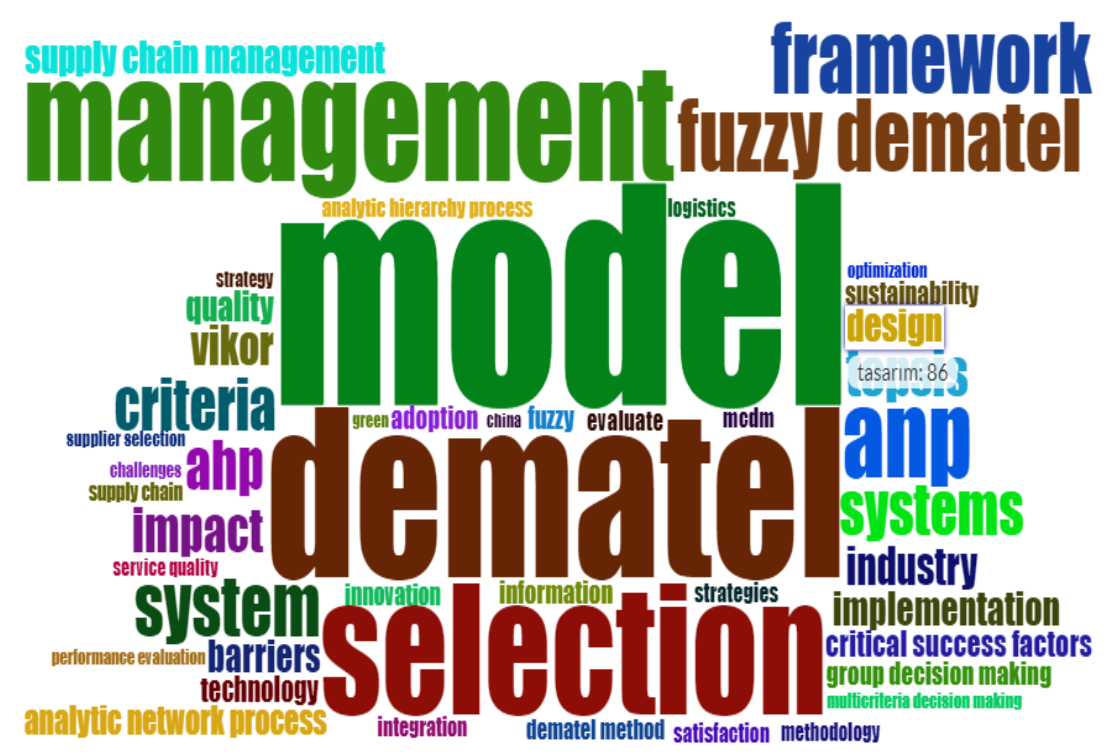

Figure 5. The most commonly used keywords in DEMATEL method

\section{Conclusion}

The focus of this study was to conduct a bibliometric analysis of global studies on the DEMATEL method, one of the MCDM methods. 1963 documents obtained from the WOS database between 1999-2020 were analyzed with the R Studio program. In the study, the annual research outputs of the researches published on the DEMATEL method, document types, countries, important journals and authors contributing to the field, the most efficient universities, and which fields of science the method is used in are shown.

In the DEMATEL method, China (553), Taiwan (519), Iran (251), India (241), Turkey (184) are among the top five countries. The most cited country in his studies was observed as Taiwan (12884). With the cooperation of Taiwan and China 74, it is in the main position of international cooperation. In the analysis, it was seen that he was actively participating in researches related to the DEMATEL method in other countries.

The most prolific authors in the field are Tzeng G.H. was seen as. Next comes Tseng M.L. (38), Dincer H. (36), Liou J.J.H. (36), Huang C.Y. (35).

When we look at the Web of Science categories, it is seen that studies are concentrated in fields such as computer science and artificial intelligence, environmental science, operations research and management science, management, green sustainable technologies, electrical electronics engineering, and industrial engineering. 
In the studies related to the field, the journal "Journal of Cleaner Production" ranks at the top with 96 studies. Then, the magazine "Sustainability" takes second place with 90 studies, and the magazine "Expert Systems With Applications" takes third place with 77 studies. The most cited journal is "Expert Systems With Applications" with 7074 citations.

The most productive university is National Chiao Tung University (Taiwan) with 102 studies. Next is Islamic Azad University (Iran) with 90 studies, followed by Nan Kai University Technology (China) in three with 86 studies.

When we look at the conceptual structure of the studies, it is seen that they concentrate on words such as model, dematel, selection, management, performance, anp, decision making, fuzzy dematel.

The findings of the study show the development of the studies in the DEMATEL method, which is the MCDM method. As a result of the evaluations, it was seen that the studies on the DEMATEL method were quite dynamic. It is possible to say that the studies on this method will increase in the following years. The methodology used can be applied to other methods and other topics.

Overall, the findings of this analysis provide a general picture of the evolution of the DEMATEL method. This can assist practitioners and academics in identifying and evaluating efforts to advance research in these areas. This will help develop new lines of research for the future and advance the use of these methods in more applications. The methodology used can be applied to other MCDM methods or other topics. Using the relative advantages of different bibliometric tools, the use of variables can be expanded.

Author Contributions: Each author has participated and contributed sufficiently to take public responsibility for appropriate portions of the content.

Funding: This research received no external funding.

Conflicts of Interest: The authors declare no conflicts of interest.

\section{References}

Abu-Taha, R. (2011). Multi-criteria applications in renewable energy analysis: A literature review. In 2011 Proceedings of PICMET'11: Technology Management in the Energy Smart World (PICMET) (pp. 1-8). IEEE.

Aytaç, M., \& Gürsakal, N. (2015). Karar verme. Dora Basım Yayın Dağıtım AŞ, Bursa.

Blanco-Mesa, F., Merigó, J. M., \& Gil-Lafuente, A. M. (2017). "Fuzzy decision making: A bibliometric-based review." Journal of Intelligent \& Fuzzy Systems, 32(3), 2033-2050.

Bai, C., \& Sarkis, J. (2013). A grey-based DEMATEL model for evaluating business process management critical success factors. International Journal of Production Economics, 146(1), 281-292.

Bragge, J., Korhonen, P., Wallenius, H., \& Wallenius, J. (2010).Bibliometric analysis of multiple criteria decision making/multiattribute utility theory. In Multiple criteria decision making for sustainable energy and transportation systems (pp. 259-268). Springer, Berlin, Heidelberg. 
Koca and Y1ldırım/Decis. Mak. Appl. Manag. Eng. 4 (1) (2021) 85-103

Büyüközkan, G., \& Çifçi, G. (2012). "A novel hybrid MCDM approach based on fuzzy DEMATEL, fuzzy ANP and fuzzy TOPSIS to evaluate green suppliers."Expert Systems with Applications, 39(3), 3000-3011.

Chang, B., Chang, C. W., \& Wu, C. H. (2011). "Fuzzy DEMATEL method for developing supplier selection criteria." Expert systems with Applications, 38(3), 1850-1858.

Chen, F. H., Hsu, T. S., \& Tzeng, G. H. (2011). A balanced scorecard approach to establish a performance evaluation and relationship model for hot spring hotels based on a hybrid MCDM model combining DEMATEL and ANP. International Journal of Hospitality Management, 30(4), 908-932.

Chowdhury, P., \& Paul, S. K. (2020). "Applications of MCDM methods in research on corporate sustainability."Management of Environmental Quality: An International Journal.

Çelikbilek, Y.(2018)." Çok Kriterli Karar Verme Yöntemleri". Nobel Akademik Yayıncılık Eğitim Danışmanlık Tic. Ltd. Şti. Ankara.

Çetinkaya Bozkurt, Ö. ve Çetin, A. (2016), “Girişimcilik ve Kalkınma Dergisi'nin Bibliyometrik Analizi”, Girişimcilik ve Kalkınma Dergisi, 11(2), 229-263.

Guerrero-Baena, M. D., Gómez-Limón, J. A., \& Fruet Cardozo, J. V. (2014). “Are multicriteria decision making techniques useful for solving corporate finance problems? A bibliometric analysis."Revista de Metodos Cuantitativos para la Economia y la Empresa, 17, 60-79.

Ellegaard, 0., \& Wallin, J. A. (2015). "The bibliometric analysis of scholarly production: How great is the impact?." Scientometrics, 105(3), 1809-1831.

Gul, M., Celik, E., Aydin, N., Gumus, A. T., \& Guneri, A. F. (2016). "A state of the art literature review of VIKOR and its fuzzy extensions on applications." Applied Soft Computing, 46, 60-89.

Govindan, K., Khodaverdi, R., \& Vafadarnikjoo, A. (2015). Intuitionistic fuzzy based DEMATEL method for developing green practices and performances in a green supply chain. Expert Systems with Applications, 42(20), 7207-7220.

Hotamışlı, M., \& Erem, I. (2014). "Bibliometric analysis of the articles published in journal of accounting and finance." The Journal of Accounting and Finance, 16(63), 119.

Hsu, C. W., Kuo, T. C., Chen, S. H., \& Hu, A. H. (2013). “Using DEMATEL to develop a carbon management model of supplier selection in green supply chain management." Journal of cleaner production, 56, 164-172.

Huang, C. Y., Shyu, J. Z., \& Tzeng, G. H. (2007). Reconfiguring the innovation policy portfolios for Taiwan's SIP Mall industry. Technovation, 27(12), 744-765.

Kahraman, C., Onar, S. C., \& Oztaysi, B. (2015). "Fuzzy multicriteria decision-making: a literature review." International journal of computational intelligence systems, 8(4), 637-666.

Karaoğlan, S. (2016). "Dematel ve Vikor Yöntemleriyle Dış Kaynak Seçimi: Otel İşletmeciliği Örneği”, Akademik Bakış Dergisi, 55,9-24. 
Lawani, S. M (1981). "Bibliometrics: Its Theoretical Foundations, Methods and Applications", International Journal of Libraries and Information Services, Cilt: 31, 4, 294-315.

Liao, H., Tang, M., Zhang, X., \& Al-Barakati, A. (2019). “Detecting and Visualizing in the Field of Hesitant Fuzzy sets: A Bibliometric Analysis From 2009 to 2018", International Journal of Fuzzy Systems, 21(5), 128.

Lin, C.L. \& Tzeng, G.H. (2009). “A value-created system of science (technology) park by using DEMATEL”, Expert systems with applications, 36(6), 9683-9697.

Lin, C. J., \& Wu, W. W. (2008). “A causal analytical method for group decision-making under fuzzy environment.” Expert Systems with Applications, 34(1), 205-213.

Lin, R. J. (2013). "Using fuzzy DEMATEL to evaluate the green supply chain management practices." Journal of Cleaner Production, 40, 32-39.

Liu, H. C., Liu, L., Liu, N., \& Mao, L. X. (2012). Risk evaluation in failure mode and effects analysis with extended VIKOR method under fuzzy environment. Expert Systems with Applications, 39(17), 12926-12934.

Liu, W., \& Liao, H. (2017). "A bibliometric analysis of fuzzy decision research during 1970-2015.” International Journal of Fuzzy Systems, 19(1), 1-14.

Liu, H. C., Chen, X. Q., Duan, C. Y., \& Wang, Y. M. (2019). "Failure mode and effect analysis using multi-criteria decision making methods: A systematic literature review."Computers \& Industrial Engineering, 135, 881-897.

Mardani, A., Jusoh, A., Nor, K., Khalifah, Z., Zakwan, N., \& Valipour, A. (2015). “Multiple criteria decision-making techniques and their applications-a review of the literature from 2000 to 2014." Economic Research-Ekonomska Istraživanja, 28(1), 516-571.

Merigó, J. M., \& Yang, J. B. (2017). “A bibliometric analysis of operations research and management science."Omega, 73, 37-48.

Morkūnaitè, Ž., Kalibatas, D., \& Kalibatienè, D. (2019). “A Bibliometric Data Analysis of MultiCriteria Decision Making Methods in Heritage. Buildings", Journal of Civil Engineering and Management, 25(2), 76-99.

Osareh, F. (1996). "Bibliometrics, citation analysis and co-citation analysis: A review of literatüre." I. Libri, 46(3), 149-158.

Peng, X., \& Dai, J. (2018). “A Bibliometric Analysis of Neutrosophic Set: Two Decades Review From 1998 to 2017", Artificial Intelligence Review, 1-57.

Renganath, K., \& Suresh, M. (2016, December). "Supplier selection using fuzzy MCDM techniques: A literature review." In 2016 IEEE International Conference on Computational Intelligence and Computing Research (ICCIC) (1-6). IEEE.

Seyed-Hosseini, S. M., Safaei, N., \& Asgharpour, M. J. (2006). Reprioritization of failures in a system failure mode and effects analysis by decision making trial and evaluation laboratory technique. Reliability Engineering \& System Safety, 91(8), 872-881.

Shgeh, J.,Wu, H. \& Huang, K. (2010). “A DEMATEL Method in Identifying Key Success Factors of Hospital Service Quality”, Knowlwdge-Based Systems. 23(3): 277-282. 
Koca and Y1ldırım/Decis. Mak. Appl. Manag. Eng. 4 (1) (2021) 85-103

Shieh, J. I., Wu, H. H., \& Huang, K. K. (2010). "A DEMATEL method in identifying key success factors of hospital service quality." Knowledge-Based Systems, 23(3), 277 282.

Stevens, R.E. (1953). "Characteristics of Subject Literatures", Chicago: American College and Research Library Monography Series 7.

Stojčić, M., Zavadskas, E. K., Pamučar, D., Stević, Ž., \& Mardani, A. (2019). “Application of MCDM methods in sustainability engineering: A literature review 2008-2018." Symmetry, 11(3), 350.

Tramarico, C. L., Salomon, V. A. P., \& Marins, F. A. S. (2015). "Analytic hierarchy process and supply chain management: A bibliometric study."Procedia Computer Science, 55, 441-450.

Tsai, W. H., \& Chou, W. C. (2009). Selecting management systems for sustainable development in SMEs: A novel hybrid model based on DEMATEL, ANP, and ZOGP. Expert systems with applications, 36(2), 1444-1458.

Tseng, M. L. (2009). A causal and effect decision making model of service quality expectation using grey-fuzzy DEMATEL approach. Expert systems with applications, 36(4), 7738-7748.

Tzeng, G. H., Chiang, C. H., \& Li, C. W. (2007). "Evaluating intertwined effects in elearning programs: A novel hybrid MCDM model based on factor analysis and DEMATEL." Expert systems with Applications, 32(4), 1028-1044.

Yang, J. L., \& Tzeng, G. H. (2011). An integrated MCDM technique combined with DEMATEL for a novel cluster-weighted with ANP method. Expert Systems with Applications, 38(3), 1417-1424.

Yıldırım, B.F., \& Önder, E. (2018). “Operasyonel, Yönetsel ve Stratejik Problemlerin Çözümünde Çok Kriterli Karar Verme Yöntemleri”. Dora Basım Yayın Dağıtım AŞ, Bursa.

Yu, D., Wang, W., Zhang, W., \& Zhang, S. (2018). “A Bibliometric Analysis of Research on Multiple Criteria Decision Making”, Current Science, 114(4), 747-758.

Wu, W. W., \& Lee, Y. T. (2007). “Developing global managers' competencies using the fuzzy DEMATEL method.” Expert systems with applications, 32(2), 499-507.

Wu, W. W. (2008). “Choosing knowledge management strategies by using a combined ANP and DEMATEL approach." Expert Systems with Applications, 35(3), 828-835.

Xia, X., Govindan, K., \& Zhu, Q. (2015). Analyzing internal barriers for automotive parts remanufacturers in China using grey-DEMATEL approach. Journal of Cleaner Production, 87, 811-825.

Zavadskas, E. K., Turskis, Z., \& Kildienè, S. (2014). “State of Art Surveys of Overviews on MCDM/MADM Methods." Technological and Economic Development of Economy, 20(1), 165- 179.

Zhou, Q., Huang, W., \& Zhang, Y. (2011). Identifying critical success factors in emergency management using a fuzzy DEMATEL method. Safety science, 49(2), 243 252. 
Biblometric analysis of DEMATEL method

Zyoud, S. H., \& Fuchs-Hanusch, D. (2017). "A Bibliometric-Based Survey on AHP and TOPSIS Techniques”, Expert Systems with Applications, 78, 158-181.

(C) (i) 2018 by the authors. Submitted for possible open access publication under the (http://creativecommons.org/licenses/by/4.0/). 